

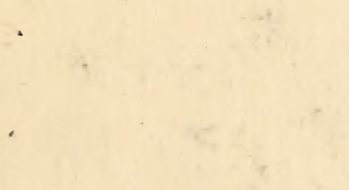





\section{MAKING A ROSE GARDEN}





\section{THE \\ HOUSE \& GARDEN \\ $M A K I N G$ \\ BOOKS}

$\mathrm{T}$ is the intention of the publishers to make this series of little volumes, of which Making a Rose Garden is one, a complete library of authoritative and well illustrated handbooks dealing with the activities of the home-maker and amateur gardener. Text, pictures and diagrams will, in each respective book, aim to make perfectly clear the possibility of having, and the means of having, some of the more important features of a modern country or suburban home: Among the titles already issued or planned for early publication are the following: Making a Lawn; Making a Tennis Court; Making a Garden Bloom This Year; Making a Fireplace; Matiing Roads and Paths; Making a Poultry House; Making a Hotbed and Coldframe; Making Built-in Bookcases, Shelves and Seats; Making a Rock Garden; Making a Water Garden; Making a Perennial Border; Making a Shrubbery Group; Making a Naturalized Bulb Garden; with others to be announced later, 




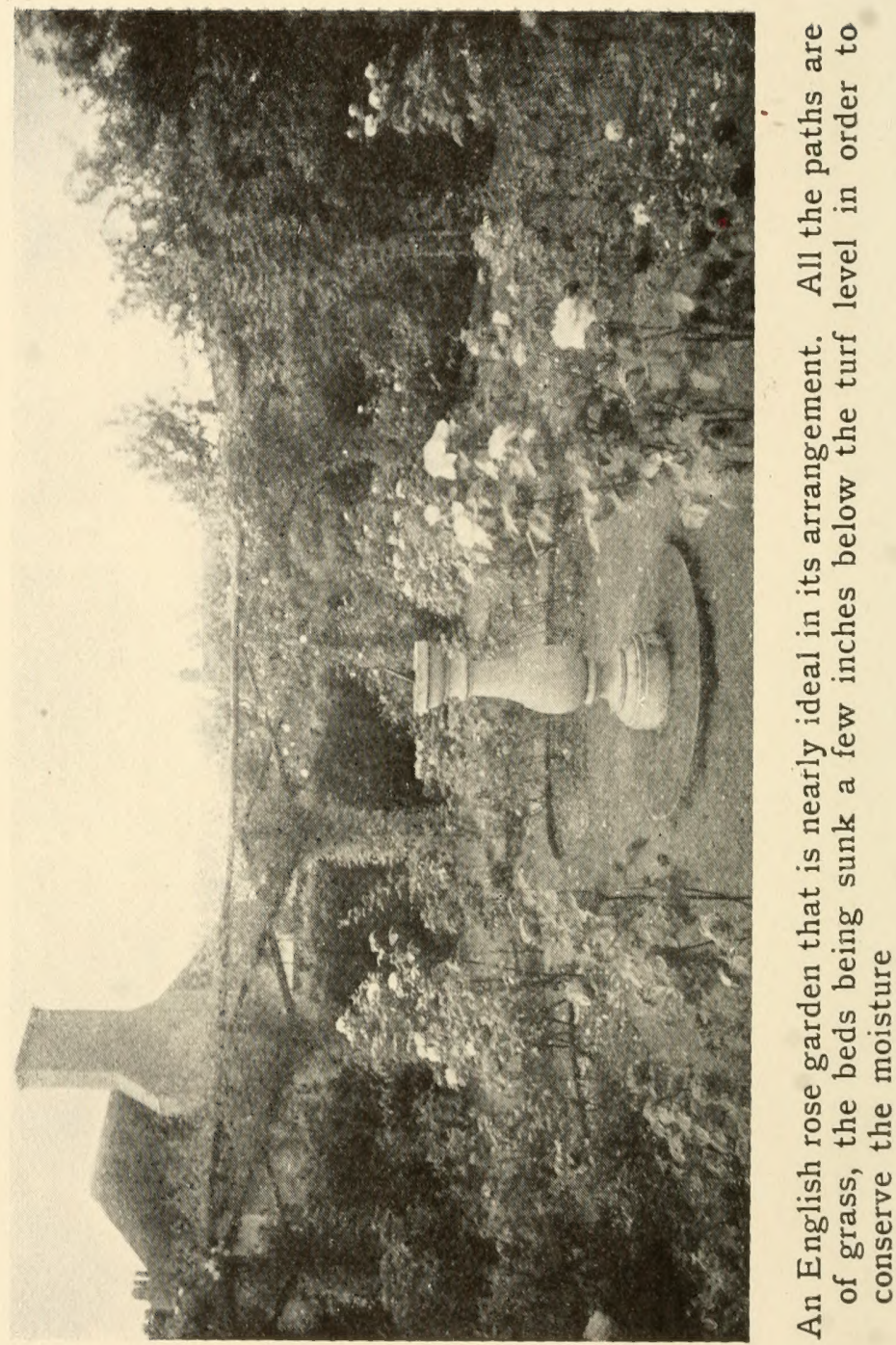




\section{MAKING A ROSE GARDEN}

\section{By HENRY H. SAYLOR}

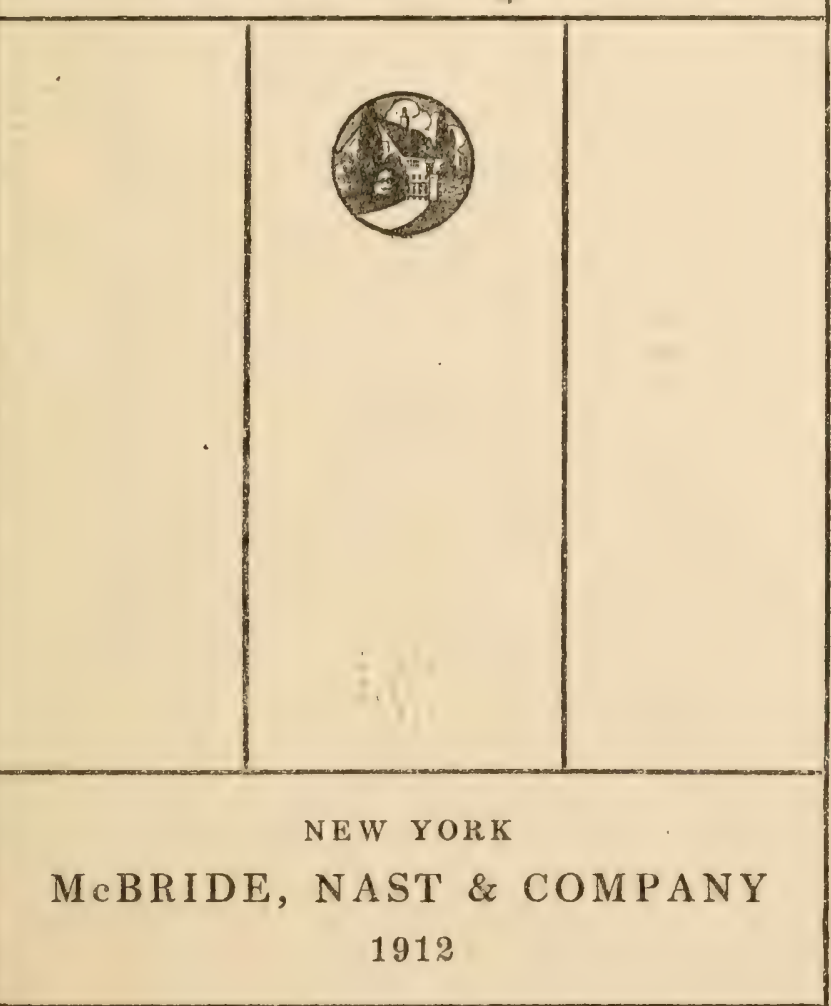


COPTRIGHT, 1912, BY MCBRIDE, NAT \& CO. .

$$
i y^{2} y^{2}
$$

Published February, 1912

$\{C H A:-3): D: D$ 


\section{O N T E T S}

PACW

INTRODUCTION . . . . $\quad 1$

Classification $\quad$. $\quad . \quad 3$

Location and SoIL • • . 11

Priparation and Planting • 20

Fertilizing • • • . 25

Pruning . $. . . \quad . \quad 30$

Pests . . ० ० ० . 33

Propagation . . . . 40

Winter Protection . . . . 44

Lists of Dependable Roses . . 46

Glossary of Terms . . . . 51 



\section{THE I L L U S T RAT I O N S}

A Rose Garden with the Ideal Arrangenent of Grass Patus

Frontispiece

FACING

PAGE

Ulrich Brunner, a Ren Hybrid PerPETUAL Rose. . . . . 4

Maréchal Neil, a Tender Cumbing Tea Rose • . . . . 8

Killarney, One of the Best Hybrid TEAS . . . . . 12

A Garden for Roses Only $\quad$. 14

A Dormant Tea Rose as It Comes FROM THE GROWER • . . 22

A Stock of Manetti Grafted with an Improted Variety . • • 42

A "Standard" Rose . . . . 44 



\section{INTRODUCTION}

WELL remember the caution given me I by a noted horticulturist when, in the sudden awakening to the joys of gardening, I was about to attempt the cultivation of nearly everything named in the largest seed and plant catalogue I could find:

${ }^{66}$ Leave the rose alone; it is not worth fighting for."

And leave it alone I did, until one day I was browsing about an old book shop and came upon a well-thumbed copy of good old Dean Hole's "A Book About Roses." Let me tell you that there is something radically wrong with the person who can read that book and then gुo on plodding along his dreary, roseless way.

But why, if there is such a book as that to be had, do I presume to put forth what can at best be but a feeble ray in its predecessor's blaze of inspiration? Merely because Dean Hole's book, and a later volume by the Rev. Andrew Foster-Melliar that is almost as inspiring, with perhaps 
even more helpful guidance, are both written for the English rosarian and for a cool, moist climate that necessitates a somewhat different method of procedure throughout as compared with that which would bring success in growing roses here in America. Then too, there is to my mind something encouraging in a very small book, a book that will merely attempt to lay the foundations for the superstructure that, after all, only experience can bring. Perhaps there are those who, like myself, are content with the bare essentials of classification, content to be told the basic rudiments of cultivation, and who are in haste to be done with all of these homely means to an end, that they may begin growing roses. 


\section{Making a Rose Garden}

\section{CLASSIFICATION}

WHEN one considers the fact that the majority of botanists recognize over a hundred species of the genus Rosa, and that a French botanist lists and describes 4,266 species from Europe and western Asia alone, it will readily be understood that this chapter can give but a rough, working knowledge of groups and species.

Fortunately the amateur rosarian in the United States is concerned with very few of the species, largely for the reason that the efforts of our rosegrowers have naturally been confined to a few important groups where general merit is most strongly marked. Indeed, for the purposes of a modest rose garden, one would not go far wrong if he limited his choice of varieties to the Hybrid Teas, Hybrid Perpetuals and a few of the Teas, with sev- 
eral of the reichuraiana and ruggosa hybrids for trellis and hedge.

The name Hybrid Perpetual is borne by an enormous group of roses which have been derived from various species, crossed and recrossed until the parentage is in most cases hopelessly involved. The "Perpetual" half of the name signifies that the rose continues to bloom more or less frequently throughout the summer. As a matter of fact, it is usually less.

Teas or Tea-scented China roses form a distinct group that is readily recognized by the characteristic scent of the flowers and by the smoothness of its leaves. 'Teas are, in a way, the aristocrats of the rose garden. They bloom with no great blare of trumpets in June, like the Perpetuals, but they keep steadily at their work of producing exquisite blooms, one or two at a time, throughout the summer. Their one serious handicap is a lack of hardiness, which they possess only in a slight and very variable degree; and they must be very carefiully protected in the north to bring them safely through the winter. Even though I were forced to buy new 


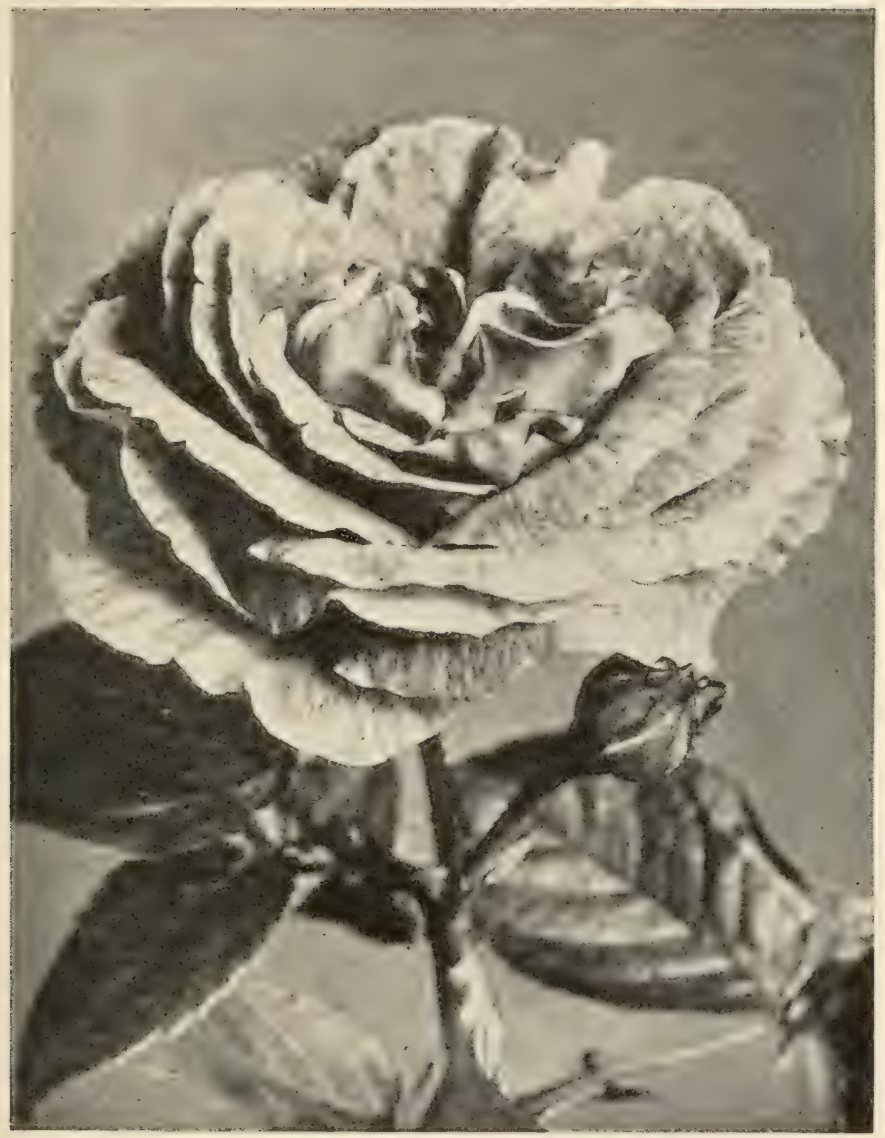

Ulrich Brunner, a red Hybrid Perpetual that has achieved an excellent reputation. The H.P. type is characterized by hardiness and great freedom of bloom in June. Thereafter throughout the summer the burden of display must be borne by the Teas and Hybrid Teas 



\section{Classification}

plants each spring, however, I would not have a rose garden without Teas.

Hybrid Teas, as the name signifies, are successful crosses between the Tea and roses in the Hybrid Perpetual group. This class combines the persistence of the Tea with the sturdier growth of the Perpetuals, and from it we shall probably get the great bulk of our garden roses for some years to come.

The Moss Rose, of which you will surely want a representative in your garden, belongs in the Provence group, as will be seen in the tabular classification at the end of this chapter. Who does not know its beautiful buds in their setting of mossy stems? This rose, like many a one that has not gotten such a grip on our affections, has refused steadfastly to mix its blood with another species, and has retained its good points and its bad ones for over three hundred years. It is quite hardy but is rather susceptible to mildew.

There are other roses, too, outside the larger and best-known groups-roses that, because of some superlative merit in one direction or because of past associations, lay a strong hand on our heart-strings and 
plead for an obscure corner of the new rose garden: the bristling Scotch Rose, the fragrant Damasks, the sweetbrier or eglantine with its inimitable fragrant foliage, the Penzance Brier Hybrids, the White Banksian of southern gardens with its odor of violets, the Persian Yellow of our grandmother's' gardens, and the hundred-petaled Cabbage Rose, parent of the Moss.

Climbing roses are to be found in many of the groups-Wichuraiana, Ayrshire, Polyantha, Musk, Noisette and as sports in the Hybrid Perpetual, Tea and Hybrid Tea groups.

It is in another class, however, that we may look for the ideal American roses of the future. Not many years ago, came to us three natives of Japan, Rosa wichuraiana, Rosa multiflora and Rosa rugosa. From the first two has been developed by our American hybridizers the race of Ramblers, while from the third has come such sturdy children as Conrad F. Meyer, perhaps the ideal hedge rose for our northern climate. In the estimation of Professor Charles S. Sargent, the dean of American horticulture, it is along the line of rugosa hybrids that we shall succeed in filling our 


\section{Classification}

gardens with large, beautiful, hardy and continuously flowering roses.

The climate of the South and California seems ideally suited to the Teas, producing a wealth of exquisite bloom that fills those of us that live in more trying surroundings with envy. In the South also they have the Cherokee Rose (Rosa lavigata or sinica), flourishing along roadsides and in great masses on the prairies, its long, arching stems bearing a wealth of pure white, single flowers, four or five inches across, in a setting of brilliant, evergreen foliage. It is one of our American hybridizerss hopes and aims to cross this with a hardy rose to gain sufficient stamina for the North.

And out in Oregon, the Hybrid Perpetuals and Hybrid Teas grow to a size and beauty that is unsurpassed the world over. Practically every kind of rose can be grown in the Puget Sound district, and the amateurs of that locality seem to have as little trouble with rose pests as we do here with our hardy decorative shrubs.

To sum up the whole matter of classification and to show the relative positions of many groups that, for lack of space, 
have not even been mentioned above, the following tabular key is given-a slightly modified form of the classification given in the Cyclopedia of American Horticulture: 1. Summer-flowering lioses, blooming once only

A. Large-flowered (double).

1. Growth branching or pendulous; leaf wrinkled.

Provence

Moss

Pompon

Sulphurea

2. Growth firm and robust; leaf downy.

Damask and French

Hybrid French

Hybrid Provence

Hybrid Bourbon

Hybrid China

3. Growth free; leaf whitish above; spineless.

Alba

B. Small-flowered (single and double).

1. Growth clinbing; flowers produced singly.

Ayrshire

․ Growth short-jointed, rुener- 


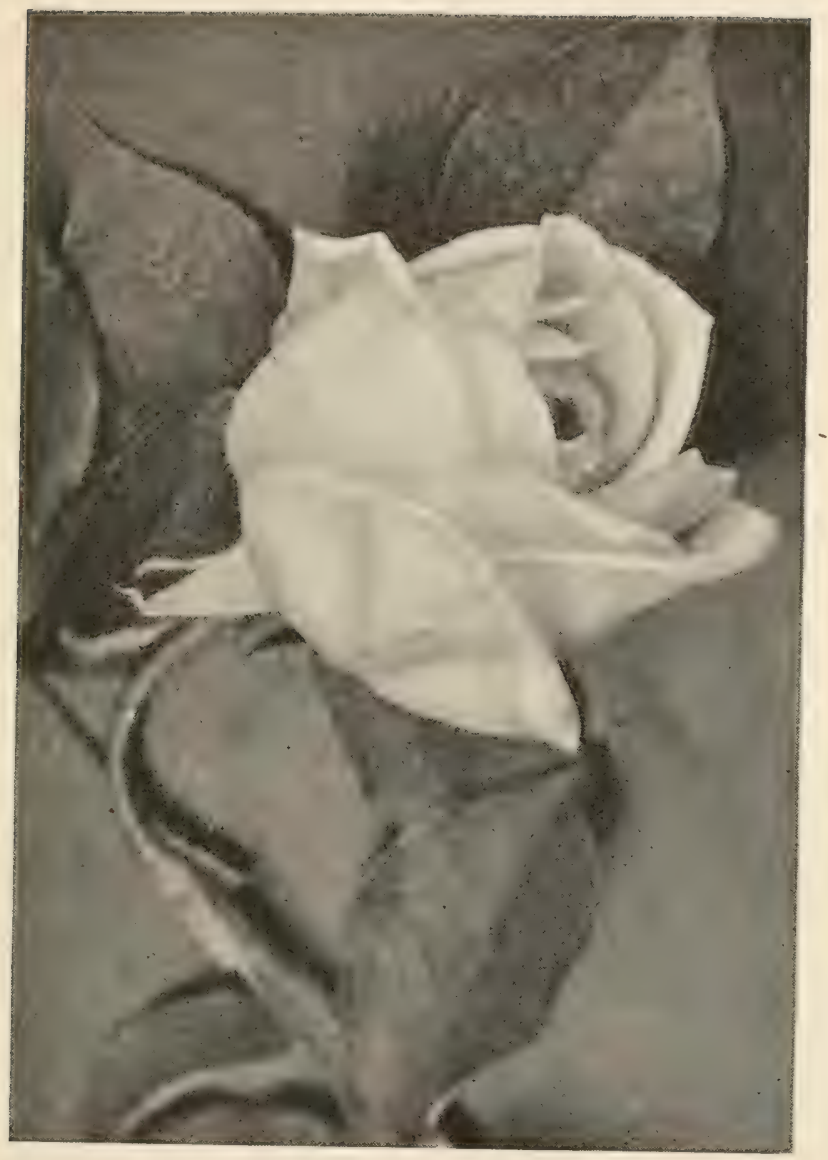

Marechal Neil, a tender climbing Tea rose, dark golden-yellow in color, requires winter protection in the North. The Tea is the aristocrat of the rose garden, unapproached for delicate fragrance, refined form of the individual blooms, and continued flowering throughout the summer 

ally, except in Alpine.

\section{Briers}

Austrian

Scotch

Sweet

Penzance

Prairie

Alpine

3. Growth climbing; flowers in clusters.

Multiflora

Polyantha

4. Growth free; foliage persistent (more or less shiny). Evergreen

Sempervirens

Wichuraiana

Cherokee

Banksian

5. Growth free; foliage wrinkled.

Pompon

II. Summer- and Autumn-flowering Roses, blooming more or less continuously

A. Large-flowered.

1. Foliage very rough.

Hybrid Perpetual

Hybrid 'T'ea

Moss 
2. Foliage rough.

Bourbon

Bourbon Perpetual

3. Foliage smooth.

China

Tea

Lawrenceana (Fairy)

B. Smaller-flowered.

1. Foliage deciduous

a. Habit climbing.

Musk

Noisette

Ayrshire

Polyantha

Wichuraiana Hybrids

b. Habit dwarf, bushy.

Perpetual Briers

Rugosa

Lucida

Microphylla

Berberidifolia

Scotch

2. Foliage more or less persistent.

Evergreen

Macartney

Wichuraiana 


\section{LOCATION AND SOIL}

I $F$ there is any secret in connection with 1 the growing of beautiful roses in abundance, it lies in the strict observance of a few fundamental principles through which the rose plants, or bushes if you will, are given a location and soil which they will find congenial and nourishing. If for one moment you may have thought that success depends upon some particular insecticide for the annihilation of the aphis, or some hard-and-fast rule for pruning, or the use of a fertilizer having magical attributes, dismiss that thought from your mind, once and for all time. Insecticides, judicious pruning and suitable manuring have each an important part in the campaign, but transcending all of these is the first choice of location and the preparation of the garden in which the roses are to grow. Warfare against the rose's enemies can be but a one-sided, hopeless struggle if we are working against nature all the way through. Far easier and more 
certain in effect will be our first efforts to establish the rose plants themsetves so firmly in healthful, congenial surroundings that they, rather than we, will bear the brunt of the battle against the insect pests.

In China I am told that a custom once prevailed whereby the emperor paid his physician a good salary as long as the ruler kept his good health. If he fell ill the physician's pay stopped; if he dicd, off came the practitioner's head.

Be generous in the amount of thought and care you give in providing health, food and strength for your rose plants, and as a result you will have to give very little thought and care to curing disease and killing off the rose-bugs and slugs.

In the first place let us take up the matter of situation. Unfortunately most of us will have little lecway in this, for the average suburban place is not one that will offer hill and valley, windswept open space and warm shelter. The ideal location is to be found neither on a hilltop where the winter winds would play havoc with our winter protection, nor in a low hollow where frosts are always more frequent. A gentle slope to the south, well above nearby 


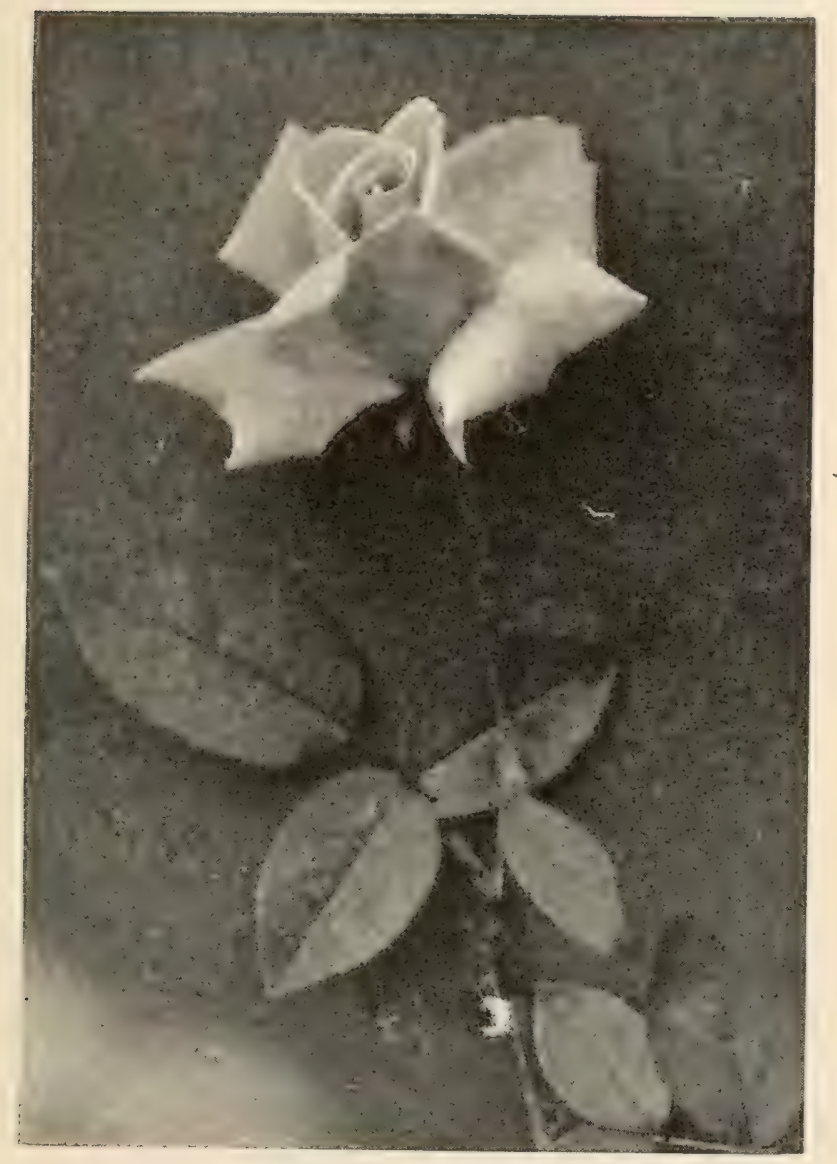

Killarney, the comparatively new Hybrid Tea rose, having a beautiful shell-pirk color, has achieved a wide popularity. The Hybrid Tea combines in a measure the hardiness of the Hybrid Perpetual with the continuous flowering habit of the Tea 



\section{Location and Soil}

low spots into which the cold air will drain, sheltered in some way from the north, would be all that we could ask. In the matter of this shelter, however, we meet a further difficulty, for our rose garden must be kept well away from any trees. It is a matter of common knowledge that the root system of a tree will, as a rule, extend as far out from the base as the tree rises about the ground. Obriously it would be merely a waste of time and effort to locate the rose garden where the hungry roots of trees would rob it of the food supply furnished the roses. In general, therefore, we shall have to use the wall of a house or a garden wall for our needed protection, though in case of necessity we could sink a masonry wall or an iron plate as a barrier between the upper rich soil of our rose beds and the roots of the sheltering trees.

Sun, it is perhaps unnecessary to say, is essential, though it will be found that if the beds are in shade for the first part of the morning one will have greater opportunity of enjoying the roses at their best -before the dew has been drunk from their petals by the thirsty midsunmer rays.

The matter of the size and design of the 


\section{4 Making a Rose Garden}

rose bed is of comparatively little importance; what really is vital, however, is that the roses be permitted to have the beds to themselves-absolutely. But recently I read a magazine article purporting to be good advice for the rose-growing amateur. Therein appeared words of regret that the rose must needs have such bare, gaunt stalks, and suggesting as a remedy the growing of some vine about the base of the bush-I am not sure, indeed, that the honeysuckle was not specifically named for the place. I can well imagine that the result might be a very beautiful honeysuckle, but we should look there for the rose in vain.

The Queen of Flowers will brook no liberties of this kind. She insists upon reigning alone in her glory, and anyone who dares presume to introduce even a low-growing, shallow-rooted ground cover with the intention of making the rose bed seem less bare, will never see his roses at their best. Personally I have never felt that a rose garden need be in the least unattractive. There is one type of beauty that might be represented by a carpet of creeping phlox; there is another that be- 


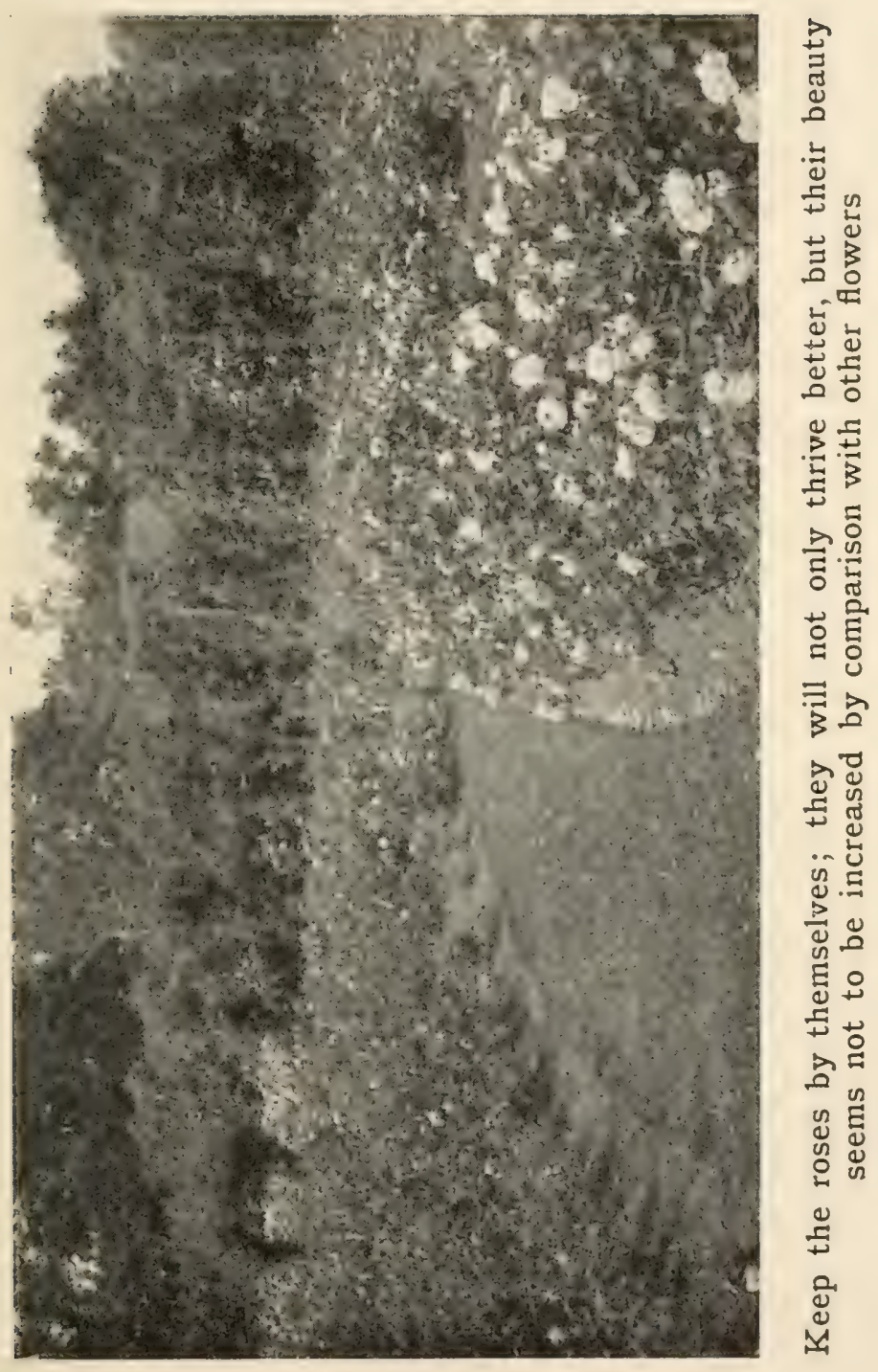



longs to the rose garden, bearing its single blooms here and there, sparsely, among the green foliage and thorny stems. In the former instance one looks at the mass effect without a thought of the beauty of individual flowers; in the latter case one's glance seeks out instinctively the single bloom to drink in its beauty and fragrance. $\mathrm{Ah}$, but you say, how about the time when there is not a single rose in sight? There need be no such time between spring and fall if you plant your rose garden to best advantage. There is no need nor reason to put all the June-blooming roses together, with the Teas and Hybrid Teas off by themselves in another place. If the remontant types are interspersed throughout your garden you need never, between May and October, look for a rose in vain. The shape of the beds, too, may be such as to avoid an appearance of "too much dirt" in the rose garden. For my own part I would have a rectangular garden and simple parallelograms for the beds, although the rose garden about a central feature has its strong attractions. But if vou arrange the beds in long narrow units

-four feet wide for a double row of 


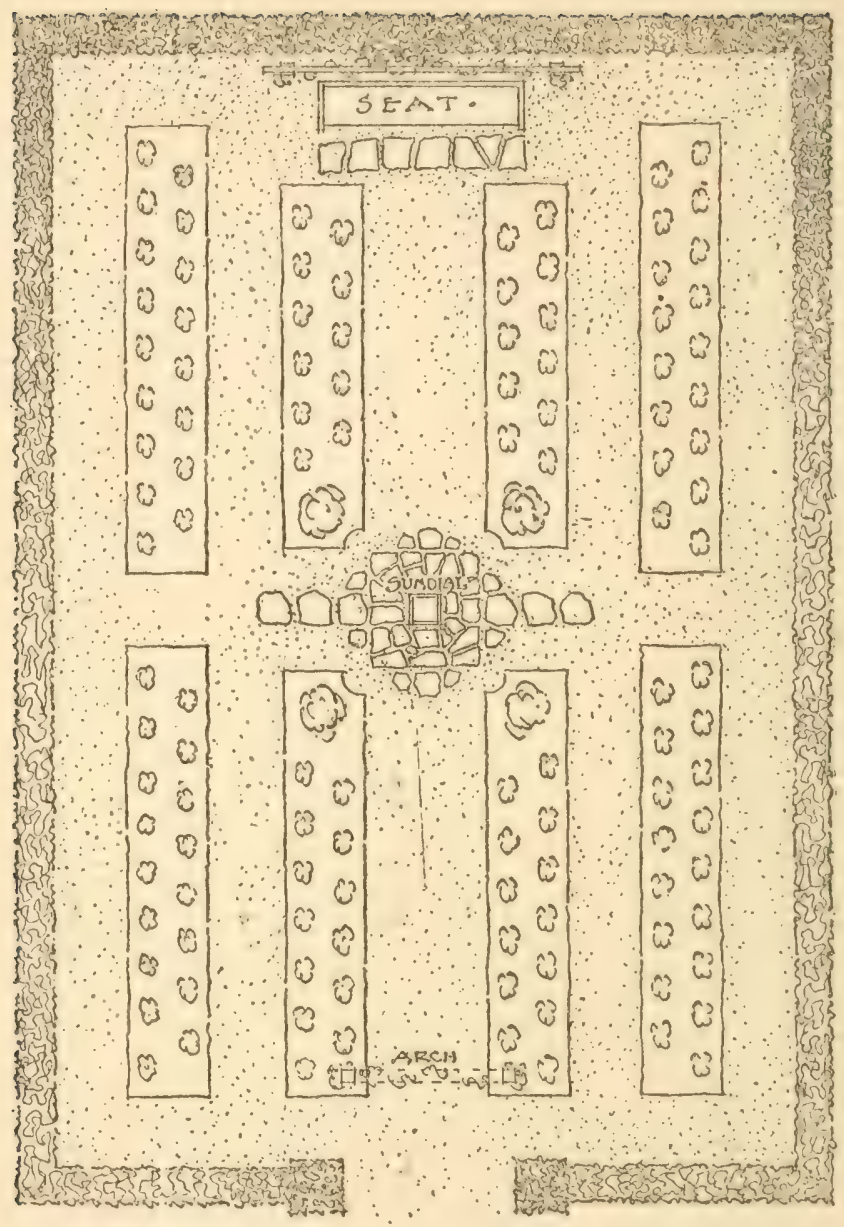

A suggestion for a rectangular rose garden with paths of turf. The beds are about forty inches wide, the paths four feet. ('xopting the center one, which is five feet in wis?th. $\Lambda$ hedere. which might be of rugosa, contributes a desirable air of seclusion 
plants or twenty inches wide for a single row, and as long as your purse will allow, having the paths between the rows of turf rather than gravel or brick, and the beds slightly sunk below this turf, the rose garden need never be less than most attractive. Avoid beds wider than will accommodate two rows of plants, for it is essential that every rose bush in the garden be immediately accessible from a path.

To those intensely practical persons who object to walking through dew-wet paths in the morning tour of the rose garden, let me point out the obvious impossibility of having gravel paths immediately adjacent to the rose beds, and the continued care required to keep in a presentable condition a narrow strip of sod between path and bed.

Now as to the preparation of the rose bed itself. First of all, dig the soil out to a depth of two feet at least, keeping the top soil and sods and the subsoil in separate piles as they are taken out. Loosen up the floor of the trench with a pick and on this, if the ground needs draining, which it will if it is a compact, sodden surface, put a layer of stones, cinders 
and other material that will not decompose. On top of this place the best of the sub-soil mixed with a generous dressing of well-rotted manure. Finally. add the sod, well broken up, and the top soil, also enriched with manure. Then fill in the bed with enough good top soil, unmanured, to bring it two or three inches above the adjoining surface. Make sure that the surface of the bed, after it has settled, will be about one inch below that of the adjoining sod in order to retain the moisture from rain. This preparation of the bed should be done at least several weeks in advance of planting time.

In composing the soil for the rose bed, it is well to remember that the Hybrid Perpetuals require a heavy soil containing some clay. For Teas and Hybrid Teas a lighter, warmer soil is better. In his most admirable "Book of the Rose," the Rev. Andrew Foster-Melliar tells an amusing incident in connection with soil. The good rector was dining out and had been served with a generous portion of plum pudding. It was very dark, rich, strong and greasy. Absent-mindedly he sat back in his chair gazing at the dish 


\section{Location and Scil}

intently. His hostess, noticing his hesitancy, asked if anything were wrong with the pudding. "Oh, no," replied the rector unthinkingly, "I was thinking what rare stuff it would be to grow roses in."

Top soil from an old pasture, if it be a moderately heavy loam, taken with the grass roots and chopped very fine, will do excellently for the Hybrid Perpetuals. For the Teas and Hybrid Teas, mix with soil of this kind about one-quarter of its bulk of sand and leaf mold to lighten it. Remember that all the manure that is used should be incorporated with the lower twothirds of the bed; the upper third should not contain any recently added manure as it is apt to harm the roots of new plants. 


\section{PREPARATION AND PLANTING}

N the vicinity of New York and further I north, I think it will be found that spring planting is best. South of Philadelphia inany reses are set out in the fall, for here they becone well established before cold weather sets in, and are therefore ready to start active growth at the first touch of "spring".

If spring planting is chosen the plants must be put in the ground early-at the very first opportunity - so that they will have time to becone firmly established before hot weather. Pot-grown plants from a greenhouse cannot, of course, be sct out until all danger from frost is past. Roses that are planted so late cannot be $\mathrm{ex}-$ pected to show really satisfying results in bloom the first year. Roses that are planted early in the spring, if field-grewn stock as explaincd below, will with proper cultivation give at least a reasonable amount of bloom the first year, though not so much as in later years. 
One hears a great deal of argument on the question of whether roses are best grown on their own roots or when grown on a sturdier stock, such as Manetti for Hybrid Perpetuals and brier for Hybrid Teas, which are probably the best rose stocks for this country. It seems to be the general consensus of opinion that roses budded on these stocks will thrive much more luxuriantly and give much better blooms than those which depend upon their own root systems. It is necessary, however, to set the point at which the shoot is budded to the stock about two inches beneath the surface; otherwise there is the constant danger that suckers will spring from the root and, if overlooked for a time, these will kill the more desirable shoots.

Several kinds of roses are offered by the dealers for setting out in the spring. There are the pot-grown roses mentioned above-the only form in which many of the climbers may be readily obtained. Mailorder houses make a practice of sending out the Hybrid Perpetuals, Hybrid Teas and Teas also in this form of very young plants grown from cuttings under glass 
during the winter. Costing more, and surely far more dependable, are the fieldgrown roses that have originally been budded on Manetti or brier and, usually in two-year-old form, taken out of the ground the previous fall while dormant, to lie in cold houses until ready for planting. Such roses as these will surely bloom the first season and are far better equipped for the shock of being set into the open ground again than the pot-grown plants that have never had a taste of real garden life.

A word of warning might profitably be uttered against the cheap roses budded on multiflora stock, grown in Holland and sold in some of the department stores. They are short-lived and very poor in comparison with plants on brier and Manetti. Multiflora has been entirely discarded as a stock by English and Irish growers.

Roses on their own roots have the advantage of being cheaper, due to the saving of labor in striking cuttings rather than budding-one-year-old plants costing a dollar for six to a dozen; two-year and three-year-old bushes, which are, of course, far more desirable, cost more in 


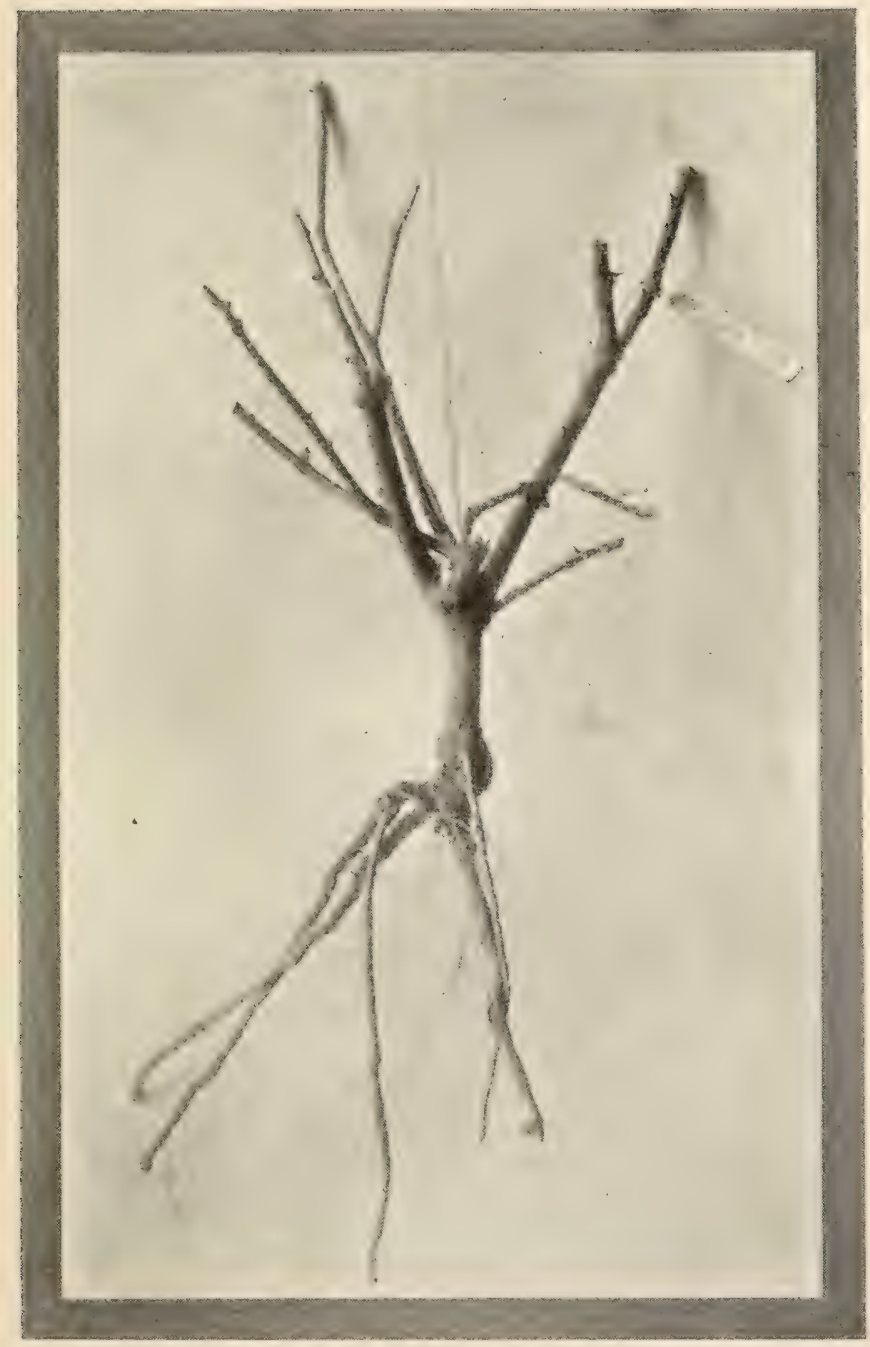

A dormant Tea rose as it is received from the grower for planting in March. After planting it should be still further pruned 

proportion. Dormant, field-grown budded roses cost, in the two-year-old size, from thirty-five cents to a dollar each.

Before setting the plants examine each carefully and cut off the broken roots with a sharp knife, as well as all eyes that may appear on the root stock, in order to forestall suckers. The plants should be set immediately upon their receipt from the nurseryman, so that they will not become dried out. If they seem dry it may be well to pudale the roots in thin mud just before setting. Make the hole large enough to accommodate all of the plant's roots without crowding, remembering to put the budding point not less or more than two inches below the surface and with the roots spread out nearly horizontally, but inclining downward towards their ends and without crossing one another. This will not be an easy matter, for in shipment the roots will have probably been so compressed that they extend almost directly downward from the collar. After the plants have been firmly set and the earth carefully packed in around the roots, rake the soil to loosen it up over the whole surface. The soil will probably 
be moist enough at the time to need no watering.

With the pot-grown plants, the moist ball of earth that comes about the roots is carefully recained intact and placed in the hole prepared for the plant. Set the plant firmly in place by pressure with the soles of your shoes, give a generous watering and finally break up the surface of the soil with a rake.

It is absolutely essential to keep the surface of the ground loosened with a hoe and a sharp steel rake throughout the summer. After very hard rain loosen the soil as soon as it is dry enough to work, to conserve the moisture. 


\section{FERTILIZING}

TN striking contrast to the exquisite 1 beauty of the rose is the food that we must give it in abundance if we would have the most healthy plants. But for the true rose enthusiast the turning over of a muck heap to find manure in just the right form, or the dilution of the byproducts of the cow barn with water to make the best stimulant, have nothing about them that is in the least objectionable.

If the soil at our disposal is inclined to be rich in clay, we can probably do no better than incorporate well-decomposed stable manure with it, by raking it, well pulverized, into the surface in the early spring. In sandy or gravelly soils, however, cow manure or that from the pigsty will serve far better. It must be remembered that when properly set out the rose plant is comparatively shallowrooted, so that this raking of fine old manure into the soil must be just that, and 


\section{Making a Rose Garden}

not the deep digging of half-rotted manure into the bed with a spading-forl. The aim in the method advocated is to put the solid manure where the spring rains will carry it in time to the feeding roots, and in the liquid form in which it is readily assimilated.

The theory of this manurial feeding will make clear the fact that a proper application of liquid manure has practically all the advantages of the former method without its drawbacks. For solid manure, if applied to the beds in quantities sufficient to be of real value, has a tendency to keep the needed air out of the top soil, and to bring in its train an abundance of weeds that will be hard to exterminate. So that, with the exception of light sandy soils, where the humus is needed, we shall do well to feed the rose garden liquid nourishment.

The time when this stimulant will be most effective is in the months of May and June, when most of the plants are putting all their efforts into the forming buds. Withhold the liquid in dry spells, for it is most appreciated immediately after a good, soaking rain. 
Avoid getting the manure on the foliage, and make sure that it errs on the side of weakness rather than strength. Suspending a burlap sack containing a bushel of cow manure in a barrel of water for two days, will give a solution that needs dilution with its own bulk of water. A half-gallon to a plant each weck will be a sufficient normal feeding.

Immediately after dosing the beds go over them with a rake or prong-hoe and loosen up the surface to prevent evaporation.

A vital principle in feeding rose plants is one that seems to be overlooked instinctively by seven out of ten amateur gardeners. It is this: A strong-growing, healthy plant needs and will absorb a large quanticy of liquid manure; a sickly plant, or one that is not yet well established, does not need and cannot absorb even the normal quantity of this food. Yet how often are we tempted to feed to excess this weakling and withhold food from that nearby sturdy bush, because the latter " doesn't need it." Just bear in mind the fact that we do not give burgundy to a puny child that is struggling against the effects of 
malnutrition, but that a healthy, growing boy can consume an astonishing amount of food and drink.

To review the year's activities in fertilizing: let us put a top dressing of rough manure over the beds in the fall, about three inches deep, with further protection where the climate demands it. In the spring we shall rake off the coarse portion of this covering, leaving the finely pulverized manure to be raked gently into the top soil if it needs this additional humus (the manure's food value will have been washed down by the winter's rain and snow). If our soil is clayey the whole top dressing will be hoed off. In May and June come the generous applications of the liquid manure, and for the Teas and Perpetuals that really do continue to fower, these applications may well be continued through the summer at less frequent intervals, leaving off at the end of August, let us say, so as not to encourage unnecessarily the late summer's growth of wood.

Although not many of us, in all probability, will meet the unusual condition of having for our rose gardens only an over- 


\section{Fertilizing}

fertilized soil in a long-used garden, it may be well to mention the fact that such a soil will not produce good roses. Treatment with lime will help matters for a time, but if within the range of possibility we should remake the garden with virgin soil.

The use of nitrate of soda and like stimulants may be undertaken sparingly in the spring, but these are better left to those gardeners who have learned, possibly through disastrous experiences, how properly to use them. 


\section{PRUNING}

TPHE rose is one of those plants that 1 seem to need the firm hand of man to direct them in the way they should grow. If left to their own devices, most of the highly cultivated roses revert quickly to lower types; they need the pitiless pruningknife to spur them to their best endeavor.

It will readily be seen that severe pruning, as a general principle, tends towards greater beauty of individual blooms, while light pruning is conducive to a better rounded-out form of bush at the expense of the flowers. Or, again, the severe pruning gives quality of bloom as opposed to quantity of bloom.

Always cut back the plants severely when first setting them out--Teas and Hybrid Teas less than the Hybrid Perpetuals, and the climbers least of all.

Unreasonable as it may seem, the plants of vigorous habit of growth need less pruning than the less active ones.

Pruning may be started with the dwarf 
Hybrid Perpetuals in March-leaving four or five canes three feet in length if large masses of bloom are wanted. The result will be a large number of small flowers. If, on the other hand, fewer and larger flowers are wanted, all weak growth should be removed and every healthy cane retained and cut back in preparation for the plant's development. The weakest should not have more than four inches of wood left on the root, while the strongest may have eight or nine inches. Always prune a cane about a quarter of an inch above an outside bud unless the cane is very far from the rertical, when an inside one should be left for the terminal shoot. See that the wood is not torn or bruised in the operation.

The pruning of Hybrid Teas and Teas had better be postponed until the first signs of life appear. The bark becomes greener and the dormant buds begin to swell. Dead or dying wood will then readily be noticeable and it may be removed. Remember that these two classes do not need such severe pruning as do the Hybrid Perpetuals; twice the amount of wood may safely be left if it seems promising. 
Dormant rose plants bought in the spring will arrive from the growers already partly pruned. In general, from one-half to two-thirds of the remaining length of cane should be cut off when the plants are set out, removing entirely all bruised or dead wood. Bear in mind always, if your conscience revolts at such severe cutting, that the strongest dormant buds are nearest the base of the plant and it is these we want to force into growth to bear the prize blooms.

With the ramblers very little cutting is needed; merely cut back the shoots that seem to be outdistancing their neighbors by too much, and cut out entirely the dead canes.

The rugosa is intended to be a bush rather than a strong, lean plant for prize blooms. Merely cut out old, dry wood and trim back the longer shoots to the desired form.

Use a first-class pair of pruning shears in order that the work may be done quickly and, above all, with clean cuts that show no tearing or abrasion of the bark. 


\section{PESTS}

NCE more let me repeat the fact that by far the most effective campaign against the insects and other pests that infest rose plants is to be found, not in sprayings and dustings, but rather in maintaining to the best of our ability a condition of health in the plant itself. Prevention here, as always, is better than cure. Nor can it be too strongly emphasized that the daily use of a powerful but finely divided spray from the hose will make life on the rose plant miserable for practically all of the parasites.

The following are the chief enemies that we may encounter in the rose garden. They are briefly described so as to be recognizable when found, and for the annihilation or kecping in check of each is given one of the many remedies. Practically every rosarian develops, after a time, his own pet formulæ for these poisons, so that rose books will be found to contain a wonderfully varied assortment of 
weapons-so numerous in fact that one would think the army of rose pests could never live to continue their depredations another season.

\section{Aphis or Green Fly}

A small, pale green louse, winged or wingless, with a soft, fat, oval body apparently too big for its legs. A single aphis in five generations may become the progenitor of $6,000,000,000$.

Tobacco smoke is an excellent weapon, or, if a spray is found more convenient to apply, a solution of $4 \mathrm{oz}$. of tobacco stems boiled for $10 \mathrm{~min}$. in $1 \mathrm{gal}$. of soft water, will do. The same weight of quassia chips may be substituted for the tobacco. If the tobacco is used, the cheapest that can be bought is the best for the purpose. Strain the solution and add $4 \mathrm{oz}$. of soft soap while it is still hot, stirring well to dissolve the soap.

Another remedy-1 qt. of soft soap boiled in 2 qts. of soft water, adding 1 pt. of paraffin before cooling-is well recommended. It should be applied diluted with soft water to ten times its bulk. The 
paraffin acts as an astringent which, together with the soft soap, cleanses the plant of honey-dew, which is exuded by the aphis to protect its feet against cold and wet.

\section{Mildew}

A fungous disease that may appear when the rose plants are in a damp, shady or ill-ventilated location. Although some varieties are more susceptible than others to this disease, the rose garden located out in the open, where the air has unobstructed access, will not be troubled much by mildew. When the disease appears late in the autumn it need not be feared.

Dusting flowers of sulphur upon the foliage, taking care to reach the under side of leaves as well as the upper, and upon the ground about the plants, is a well established remedy. It will be found convenient to shake the powder from a baking-powder can, the end of which is punched with holes, if a regular powder gun is not at hand. Use the sulphur in the early morning, when the dew will help to hold it on the leaves, or else spray the plants with water beforehand. 


\section{Rose Thrip}

A small, yellowisli white insect with transparent wings, usually found on the under side of the rose leaves. 'This pest appears in swarms and in an astonishingly short time turns the foliage yellow.

If the pest appears, spray the rose plants daily with a hose as suggested above. If this does not prove efficacious, dust the under side of the leaves with white hellebore in a powder gun. Whale oil soap solution, in the proportions of $5 \mathrm{oz}$. of soap to 1 gal. of water, is a very good remedy. It is easier to dissolve the soap if the water is hot.

Rose Caterpillar or Leaf-roller

Several kinds of caterpillars may appear, varying from one-half to three-quarters of an inch in length, and either green, yellow or brown in color. They have a habit of enveloping themselves in the rose leaves, or boring their way into the flower buds. In the latter case they are very apt to be overlooked.

Powdered hellebore will hinder their progress, but by far the most effective 
weapons are the finger and thumbgloved, if you insist.

\section{Rose Chafer or Rose-bug}

This brown beetle, less than one-half inch in length, is one of the best-known rose pests. It is a slow-moving creature that appears suddenly in armies in the blooming season in June, and is the more annoying for the reason that it devotes its attention almost entirely to the flowers themselves.

Paris green, dusted over the plants, will kill the pest, but this poison has a disagreeable way of showing no intelligent discrimination in the choice of its victims. Really the only satisfactory method of attack is to knock the stupid creatures off the flowers into a tin of kerosene and then burn it.

\section{Rose Slug}

The larvæ of a saw-fly which comes up out of the ground in May and June. The female makes incisions in the leaves and deposits her eggs, which hatch out in about two weeks. The slugs will eat an astonishing amount of leaf if not checked. They 
are about a half-inch long, green, and will be found on the upper side of the leaf.

Powdered white hellebore, dusted on the foliage, or the solution of whale oil soap mentioned for the Rose Thrip, will keep it in check.

\section{White Grub}

An underground enenry that feeds on the roots of rose plants. The withering or sickliness of the plant is suficient reason to cause a thorough search to be made by lifting it. The grub, which is provided with six legs near the head, and which coils itself into a crescent shape when in repose, is particularly fond of strawberry plants, so it will be well to keep these some distance away from the rose garden.

There is no insecticide that will be effective, because of the underground point of attack. Lifting the plant and removing the grub is the only thing that can be done.

\section{Bark Louse or White Scale}

This appears when the rose bush is grown in a damp, shady place. It is snow 


\section{Pests}

white and individual scales are about onetenth of an inch in diameter, irregularly round.

Cut off and burn badly infested shoots. Spray with $1 \mathrm{lb}$. of soap in 1 gal. of water in early winter and again in early spring. Weaker summer applications may be used also-1 lb. in 4 or 6 gal. once in three weeks throughout the season will reach all the larvæ.

\section{Our Allies}

It is well to remember that there are friends of the rose in the lower animal world as well as enemies - the toad, ladybug, ground-bird and swallow, particularly. 'The toad is sometimes brought by the English gardeners from a distance to help wage war on the pests; the lady-bug may be passed thankfully by when seen; and it may be well to try attracting the birds to the rose garden by scattering a few crumbs there daily-not too many, but just enough to arouse a real appetite for insect pests. 


\section{PROPAGATION}

THE propagation of his own stock is 1 a task for which the expert is better fitted than the beginner for whom this book is written. Nevertheless, I doubt whether the amateur will pass through his first year of rose growing without wishing to make an attempt to multiply the stock of those roses which have with him been most successful, or to bud a choice variety from a friend's garden on the foster-parent stock for his own place.

Whereas in England the process of budding is carried on very widely and with fair success among amateur and professional rosarians alike, with us this means of propagation seems fraught with greater difficulty. Excepting in the case of varieties that do not readily root from cuttings, this latter method of propagation is generally adopted where roses on their own roots are desired.

The best time for taking cuttings from a plant is towards the end of the summer, 
when the ripe wood of the current year's growth will be available. Ten inches is a convenient length for the pieces and some rosarians feel that if a "heel," or portion of older wood, remains on the lower end there will be greater likelihood of rooting. Remove all but the two top leaves and set the cutting in a light soil, or even in pure sand, so that only the two upper buds are exposed. Leave the cuttings in the ground until the following autumn, when those that have taken root may be transplanted and set at a less depth in their permanent quarters.

Budding is a far more interesting process to carry through, and by it we may have sturdier roses on a stock like Manetti or brier. A very sharp lnife is required, with some raffia for tying the bud securely into the stock. In the limited scope of this book I can but indicate very roughly the general procedure, and, indeed, budding is far more readily learned by watching a skilled rosarian do it than by reading many pages of description. Bricfly, then, a bud, which may be found under any petiole, is carefully sliced, with its surrounding bark and backing of wood, 
from the half-ripe stalk of the variety to be propagated, leaving the petiole in place to serve as a handle. This is probably best done in July. After remoying very gently the wood backing from the bark and bud, the latter are slipped into a Tshaped incision in the foster stock, this incision to be made through the bark to the actual wood of the stalk. The bud and its supporting bark are inserted between the wood and bark of the stock, the latter then being wrapped with a few turns of raffia to hold the bud in place. After a period of a month the bud will either have taken hold or failed, and the tie may be removed.

The rose plants that we buy already budded on Manetti or brier are produced in this way, excepting that the bud is inserted very low on the stock, so that the junction will be underground. This is the more desirable place for budding, insuring, if we nip the suckers as they may appear, a plant that above ground shows only the shoots of the desired variety.

Grafting is practiced only in the case of roses grown under glass, when the scions 


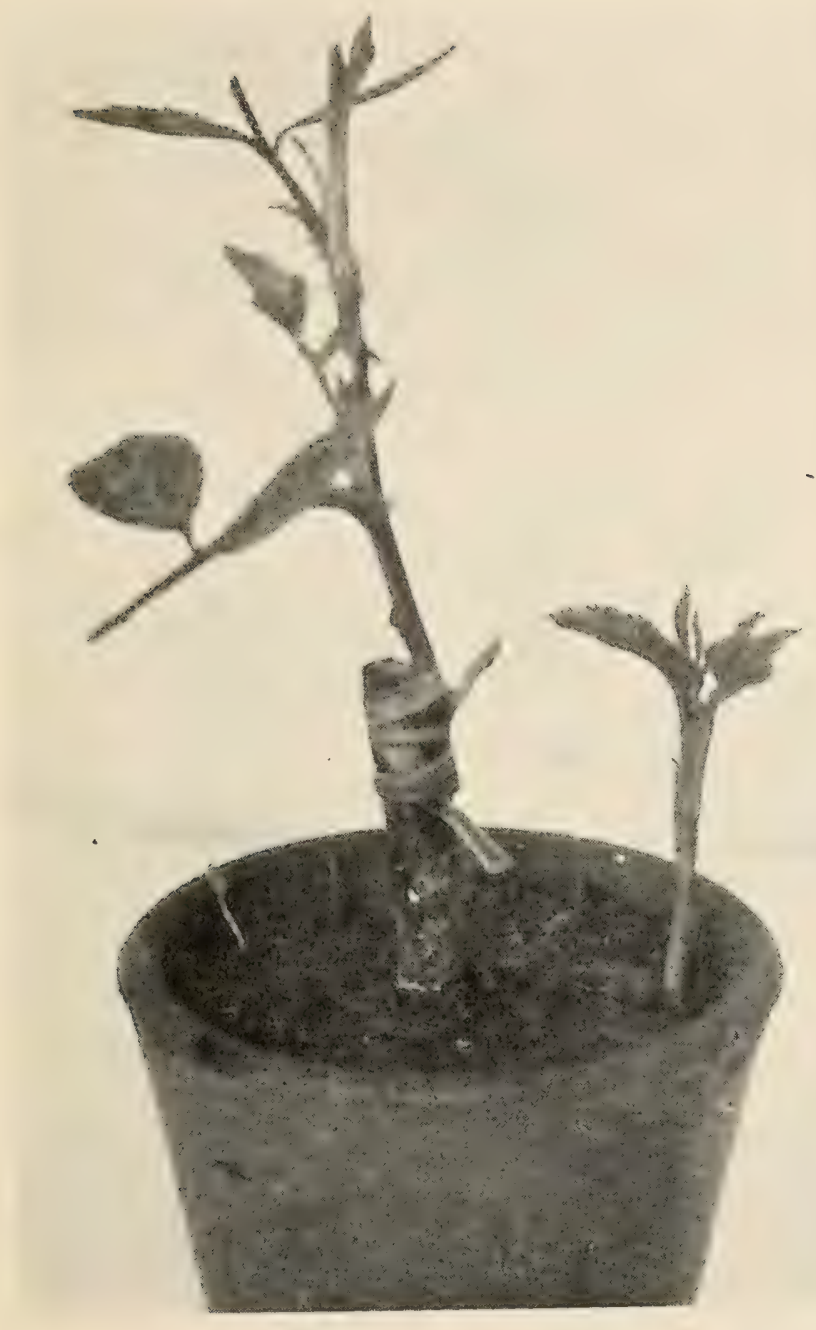

A shoot of an improved variety of rose grafted and held in place with raffia to the stock of a sturdy growth like Manetti. At tine right is a "sucker" or growth from the root, and it must be cut off as soon as it appears 



\section{Propagation}

are cleft into stocks of Manetti or brier grown in pots for the purpose.

Layering is used as a means of increasing the stock only in the case of roses that do not readily strike from cuttings. It consists of bending down a long shoot so that a section of it may be pegged un- derground to take root.

Propagation by seed is limited to the efforts to obtain new varieties after crossfertilization, and is a discouragingly slow and uncertain process. 


\section{WINTER PROTECTION}

$T$ will be a red-letter day for amateur 1 rosarians when the existing favorites among rose plants shall have been so improved by cross-breeding that we can leave off all the winter overcoats of straw, brush and earth, with the happy knowledge that spring will find as many live plants in the rose garden as we rejoiced in during the previous season.

Although the Hybrid Perpetuals are, for the most part, sufficiently hardy to withstand an ordinary winter unprotected, it is still the part of wisdom to conserve their energy and health by hoeing up the earth about their bases and putting over all a top dressing of rough manure when protecting the Hybrid Teas and Teas. In the northern states it will be well to tie up the tops of the latter with straw or to surround the bed with a border of boards or wire netting, after winter has set in, and cover the plants with a thick blanket of leaves held down by brush. This protec- 


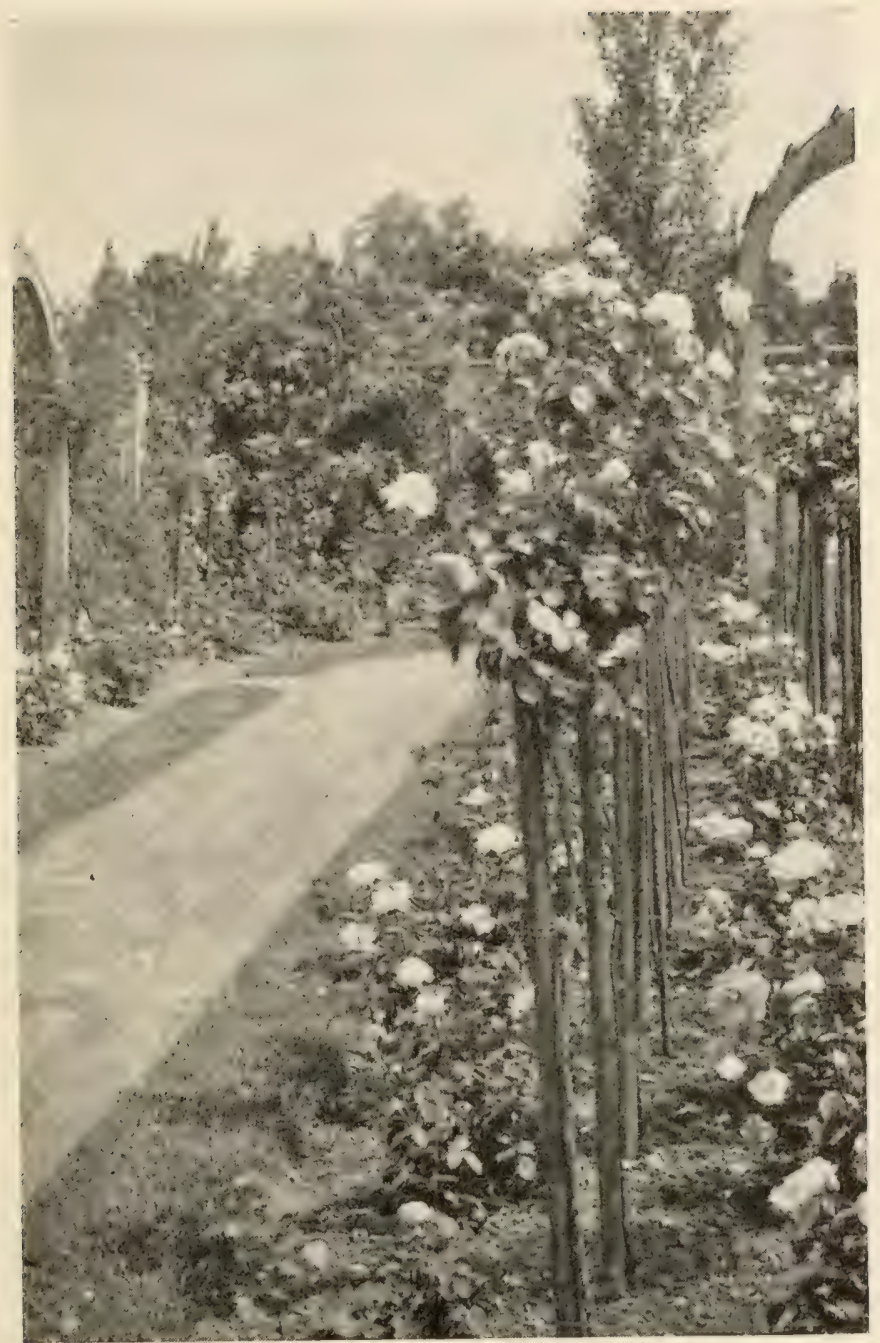

In England the "standard" rose, having a long stem of the foster stock, is quite common. With us it is less frequently seen on account of the bother of proper winter protection 

tion should be removed gradually in March.

Where the winters are particularly severe, a still more certain precaution is to dig up the plants and lay them in welldrained trenches, covering them with earth and a further layer of leaves, straw or brush. The aim is not to protect the plants from freezing at all, but to prevent the alternate freezing and thawing that is so disastrous.

Another treatment for tender roses is to winter them in boxes of soil in a cool cellar. In case this is done, see that the earth is not allowed to dry out entircly. At planting time in the spring the dormant plants will be taken out, dipped in a bucket of thin mud and replanted in the garden.

While we may be willing for the present to take such precautions with the garden roses, most of us will not care to coddle the climbers to anything like this extent. Beyond hoeing up a mound of earth about the bases of these and top-dressing them, we shall let the climbers fight their own battles, and leave the result to the principle of the survival of the fittest. 


\section{LISTS OF DEPENDABLE ROSES}

$\mathrm{T}$ is a difficult matter, indeed, to select, 1 from the expericnce of rose growers and from the long lists of the nurserymen's catalogues, a few that may be safely named as the best roses. In fact, it is a task that no one would care to undertake. It may be helpful, however, to add the following list; these are by no means the only good roses, but in choosing any or all of these the amateur cannot well go astray. For the benefit of his experience and advice regarding these lists, I am indebted, among others, to Dr. Robert Huey, of Philadelphia-probably the most experienced amateur grower of roses in the United States.

It has been thought best not to attempt individual descriptions nor to go very far into details of color. The lists, then, are grouped into rough sub-divisions under the main colors, and it will be understood that " pink," for instance, will include a rather wide range of varying tints. 


\section{Hybrid Perpetuals}

White-Merveille de Lyon, White Baroness, Frau Karl Druschki, Margaret Dickson, Mabel Morrison, Gloire Lyonnaise (in reality a Hybrid Tea, but as it blooms only in June it may be included in the Hybrid Perpetual class).

- Pink-Baroness Rothschild, Caroline D'Arden, Heinrich Schultheis, Her Majesty, Lady Arthur Hill, Mrs. George Dickson, Mrs. Harkness, Susan Marie Rodocanachi, Mrs. John Laing, Paul Neyron, Marie Finges, Marquise de Castellane, Mrs. R. S. Sharman-Crawford, Souvenir de la Malmaison.

Red - Captain Hayward, Fisher Holmes, General Jacqueminot, Oscar Cordel, Ulrich Brunner, Duke of Edinburgh, Duke of Teck, Anne de Diesbach, Duke of Fife, Étienne Levet, Prince Arthur, Ard's Rover (climber).

Prince Camille de Rohan is the best of the very dark roses, among which also are Sultan of Zanzibar, Louis Van Houtte, and Xavier Olibo. These, however, are weak growers and frequently do not bring their blossoms to perfection. 


\section{Teas}

White-White Maman Cochet, Hon. Edith Gifford.

Pink-William R. Smith, Maman Cochet, Souvenir d'un Ami, Duchesse de Brabant, Mrs. B. R. Cant.

Yellow-Harry Kirk, Étoile de Lyon, Francisca Krueger, Isabelle Sprunt, Safrano, Marie Van Houtte.

\section{Hybrid Teas}

White or light-colored and mixedViscountess Folkestone, Pharisaer, Molly Sharman-Crawford, Ellen Wilmot, Grace Molyneaux, Antoine Revoire, Joseph Hill, Mrs. A. R. Waddell, Betty, Prince de Bulgarie, La Tosca, Kaiscrin Augusta Victoria.

Pink-Killarncy, Lady Alice Stanley, Lady Ursula, Dean Hole, Lyon Rose, Dorothy Page Roberts, Madame Edmée Metz, Lady Ashtown, Mrs. Charles Custis Harrison, Caroline Testout, La France.

Ycllow-Duchess of Wellinģton, Mrs. Aaron Ward, Madame Ravary, Madame 
Mélanic Soupert, Madame Hector Leuillot, Melody.

Red-George C. Waud, Lawrent Carle, Gruss an Teplitz, Château de Closvoges, Étoile de France.

\section{Moss Roses}

White-Blanche Moreau. Pink-Crested Moss.

\section{Rugosa and Its Hybrids}

White-Blane Double de Coubert; Rosa rugosa, var. alba.

Pinl-Conrad F. Meyer.

Red-Arnold; Rosa rugosa, var, rubra.

\section{Wichuratana Hybrids}

White-Wichuraiana, White Dorothy. Pink-Lady Gay, Dorothy Perkins, W. C. Egan, Sargent. Ked-Hiawatha.

\section{Noisettes}

Yellow-Cloth of Gold, Rêve d'Or (climber), Fortune's Yellow. 
50 Making a Rose Garden

\section{Polyanthas}

White-Trier, Catherine Ziemet. Pink-Tausendschön, Clothilde Soupert. Red-Carmine Pillar.

\section{Prairie Roses}

White-Baltimore Belle.

Pink-Rosa setigera.

Austrian Briers

Yellow-Harrison's Yellow, Persian Yellow, Austrian Copper. 


\section{A GLOSSARY OF 'TERMS}

Anther-a rounded knob-like form at the top of the stamen, containing the pollen.

Callus-a swelling which occurs at the base of a cutting previous to the formation of roots.

Calyx - the narrow green leaves or sepals forming the covering for the bud.

Corymb-a group of flower stalks arising from a common stalk and forming a level top.

Cutting - a section of a stalk containing several eyes or dormant buds, taken for the propagation of a new plant.

Disbud-to deprive a stalk of flower buds by pinching or rubbing these off. It is done in order to throw more energy into the remaining bud or buds.

Hep or hip - the seed pod.

Hybrid-a new species resulting from the cross-fertilization of two species.

Leaflet-a single member of the compound leaf borne by all rose plants.

Maiden plant-a plant blooming for the 
first time after being budded or grafted to a stock.

Ovary-the hollow lower end of a pistil, containing the embryo seeds:

Panicle-a cluster of flowers borne irregularly on a stem.

Petiole-the stalk to which the several leaflets are attached.

Pistil-the seed-bearing organ in the center of a flower, consisting of one or more styles, one or more stigmas and the ovary.

Pollen - the powdery substance found in the anthers.

Remontant-applicd to roses that flower the second time in a summer.

Sepals - the narrow green leaves of a pithy texture forming the calyx.

Sport-a shoot or sucker from a plant, showing some peculiar feature or features distinguishing it from its parent.

Stamens-the male organs surrounding the pistil.

Stigma-the upper end of the pistil, capable of receiving the pollen and connected with the ovary by a tube extending down through the style. 


\section{A Glossary of Terms $\quad 53$}

Style-the erect columnar support of the stigma.

Sucker-a branch or shoot procceding from the root or stem of a plant, below the surface of the ground. Frequently used as meaning a shoot from the rootstock of a budded or grafted plant. 


$11 \quad 1912$ 



\section{LIBRARY OF CONGRESS

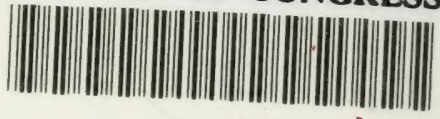 00009200010}

